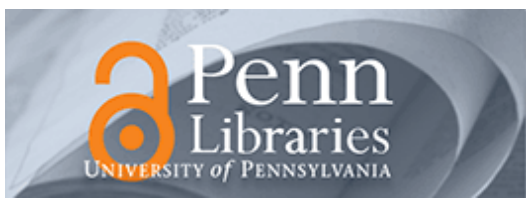

University of Pennsylvania
ScholarlyCommons

Departmental Papers (ASC)

Annenberg School for Communication

2012

\title{
Orbiting Hate? Satellite Transponders and Free Expression
}

Monroe Price

University of Pennsylvania, Mprice@asc.upenn.edu

Follow this and additional works at: https://repository.upenn.edu/asc_papers

Part of the Speech and Rhetorical Studies Commons

\section{Recommended Citation (OVERRIDE)}

Price, M. (2012). “Orbiting Hate? Satellite Transponders and Free Expression” in Michael Herz and Peter Molnar, (eds.), The Content and Context of Hate Speech: Rethinking Regulation and Responses (pp. 514-537). Cambridge University Press. 


\section{Orbiting Hate? Satellite Transponders and Free Expression}

\section{Disciplines}

Communication | Social and Behavioral Sciences | Speech and Rhetorical Studies 


\title{
Orbiting Hate? Satellite Transponders and Free Expression
}

\author{
Monroe E. Price
}

\section{INTRODUCTION}

In this chapter, I deal with the consequences of two significant changes: an expansion - a rather substantial one - in the categorization of various kinds of expression under the loose rubric of "hate speech" and simultaneously the increasing use of satellites to hurl this speech around the world. I examine a series of case studies dealing with programming transmitted by satellite that is connected to division and conflict - in these cases, conflict mostly related to societies in the Middle East.

One might anticipate that regulatory crises occur when organized and often status quo-disruptive senders shape a persistent and effective set of messages to be transmitted within a society and/or across national boundaries as part of an overall effort to gain substantial influence on target populations. As the case studies will show, when such messages have been transmitted by satellites, they have produced decisions by governments and powerful groups that have been almost invisible and exist outside a clear legal framework of articulated norms and transparent processes. One feature is paramount: Formal regulation of the content of satellite transmissions, including of speech with alleged attributes of hate, with few exceptions, rarely has been an effective theater for playing out governmental interests in satellite signal diffusion. There is also a lack of scholarly literature on the ways in which governments seek to control or affect the functioning of satellite services and their transnational distributions. In a sense, this underscores a major point: Decisions to allow or prohibit distribution of satellite signals have been treated more as strategic business decisions than as an interplay between national interests and free-expression values. Having these decisions take the form of leasing and subleasing of transponders, they become mere economic transactions, underplaying their role as modes of intervening in

Versions or portions of this chapter appeared in Comp. Media L.J., No. 16, p. 127 (July-Dec. 2010), as "Satellite Transponders and Free Expression," 27 Cardozo Arts \& Ent. L.J. 1 (2009), and as "Governance, Globalism and Satellites," 4 Global Media \& Comm. 245 (2008). 
national public spheres. In addition, because there is a relative absence of judicial decisions or similar official documents, observers must rely largely on reportorial and journalistic accounts and on information gleaned from Web sites and other unofficial sources.

The challenge is to extract from the anecdotal a better understanding of the strategic decisions being made, of what amounts to a "common law" of what kinds of content states informally ban on satellite and, even more specifically, of the interactions between content and the instruments of power. Instead of a deliberate system, there exists a hodgepodge of practices and efforts, often desperate, by states or regional and international entities to intervene when a crisis occurs or is perceived to occur. ${ }^{1}$ As I shall note, there is the beginning of a tendency to render these decisions more formal. Only then will there be the possibility of a rule-of-law analysis of the quality and defensibility of state decisions.

The international debate over how and whether to regulate satellite transmissions has gone through several phases, starting with an extensive effort (that ended in tatters) in the United Nations to design a system of international standards. ${ }^{2}$ Ownership and control have affected the debate in all its phases, and strategic considerations have played a role in the ownership structure of satellites from the outset. Initially, satellites were in transnational hands or controlled by the United States. The creation of Intelsat as a public entity was a way of acknowledging the conditions of control that might accompany an entirely new mode of transmitting information. 3 It was hardly an implementation of unfettered access to transponders. Privatization of satellites and competition removed one of the more automatic modes of control. 4 Now, in the post-g/11 world, after the industry has grown, and as the world seems more preoccupied with the role of mediated expression in the battle for hearts and minds, there are renewed attempts at regulation and control, using "hate speech" like labels as justification. The considerations that informed the first stage - the

1 Given the magnitude of the subject, the scope of the discussion is limited in this chapter. For example, the International Telecommunications Union and governance in terms of the allocation or assignment of orbital slots is addressed. The debate there concerning equitable distribution of orbital positions and first come-first served, has been often told. This chapter will focus on a line of questioning arising out of an earlier work, Monroe Price, "Satellite Broadcasting as Trade Routes in the Sky," in In Search of Boundaries: Communication, Nation States and Cultural Identities 146 (Joseph M. Chan \& Bryce T. McIntyre eds., Ablex Publishing 2002). The question raised there is whether, rather than looking for a universal or global governance scheme, we can identify different regional themes, different forms of state intervention that turn on particular satellites, particular footprints, or particular content. Put in metaphorical terms, does the law governing this trade depend on the ship, the port of call, the freight, or some combination thereof?

2 See Kathryn M. Queeney, Direct Broadcast Satellites and the United Nations (Sijthoff \& Noordhoff 1978).

3 See Leland L. Johnson, The Future of INTELSAT in a Competitive Environment (Rand Corp. 1988); Kenneth Katkin, "Communication Breakdown?: The Future of Global Connectivity after the Privatization of INTELSAT," 38 Vand. J. Transnat'l L. 1323 (2005).

4 See Katkin, supra note 3. 
UN debate - are present again, but the geopolitical considerations mean different positions for key players. ${ }^{5}$

\section{THE UNITED NATIONS, THE PRIOR CONSENT DEBATE, AND THE ARTICULATION OF ISSUES}

"Freedom of expression" norms and their application to hate speech arose at an early stage at the UN. Almost as soon as the extraordinary science-fiction laden prospect of direct-to-home satellite communication became widely seen as actually possible, the UN took up the question of whether international regulation would be desirable. After all, the sending of a signal from one country into the territory of another could be seen either as a triumph of free expression or as a potential violation of national sovereignty (or both). ${ }^{6}$ Indeed, most terrestrial broadcasting regulation, at least on the multilateral level, had been established on the idea that in medium- and long-wave there should be some sort of agreement for the management of broadcasting signals so that national borders were respected and what might be called "intended spillover" was minimized. ${ }^{7}$ A similar idea - requiring prior consent before a satellite signal is sent transnationally - was debated in both the UN and the UN Education, Scientific and Cultural Organization ("UNESCO") from the late 1960s to the early 1980s.

5 For example, Canada's novel mode of determining whether $\mathrm{Al}$ Jazeera could be carried on cable services; the application of the U.S. Terrorism Exclusion list in the case of Al Manar; and domestic informal and formal pressures related to the difficulty of Al Jazeera International in gaining shelf space on U.S. cable systems.

6 See Colby C. Nuttall, "Defining International Satellite Communications as Weapons of Mass Destruction: The First Step in a Compromise Between National Sovereignty and the Free Flow of Ideas," 27 Hous. J. Int'l L. $3^{89}$ (2005) (discussing the framing of the debate as conflicting perspectives of governing principles, with some states supporting a "free flow of information" and other states supporting "national sovereignty").

7 For most of the twentieth century, the international consensus was that radio transmissions should be contained primarily within the boundaries of one nation; the international function, performed mainly through the International Telecommunications Union ("ITU"), was to dispense frequencies so as to assure that conditions of market division along national borders could be realized and enforced. Between the world wars, there were bilateral and multilateral agreements to control propaganda subversive to the state system. For example, the League of Nations sponsored the International Convention Concerning the Use of Broadcasting in the Cause of Peace, which provided:

The High Contracting Parties mutually undertake to prohibit and, if occasion arises, to stop without delay the broadcasting within their respective territories of any transmission which to the detriment of good international understanding is of such a character as to incite the population of any territory to acts incompatible with the internal order or the security of a territory of a High Contracting Party.

International Convention Concerning the Use of Broadcasting in the Cause of Peace, Sep. 23, 1936, 186 L.N.T.S. 301 art. 1 (1936) (highlighting states' continuing "struggle with the question of whether to use law to protect transnational systems or to enhance international freedom to communicate").

8 For details of debates on the prior consent requirement in particular and regulation of direct broadcasting by satellite in general, see Queeney, supra note 2; National Sovereignty and International 
The main forum for this debate was the UN Committee on the Peaceful Uses of Outer Space ("COPUOS"), ${ }^{9}$ which was established in 1958 and was responsible for creating the five major treaties that regulate activities in space. These treaties concern: the use and exploration of space; the rescue and return of astronauts and objects launched into space; liability for damage caused by space objects; registration of objects launched into space; and the use and exploitation of the moon. ${ }^{10} \mathrm{Mem}$ bers of COPUOS's working group argued for "a prohibition on broadcasts beamed from satellites by one State to others without the explicit prior consent of the Government concerned through bilateral or multilateral agreements." ${ }^{\prime 11}$ Quite quickly, the debate became a forum for rehearsing Cold War feints and parries, and for consideration of the relationship of satellite transmissions to spheres of influence. The Soviet Union, supported by many developing countries, fought for a prior-consent requirement (the USSR claiming it desired to limit political propaganda and hateoriented speech, others more concerned with the impact on economic development and cultural heritage). Arguments over what were called direct broadcasting services were linked closely to debates on the free flow of information and agitation for the "New World Information and Communication Order." ${ }^{12}$ The United States, along with several allies, opposed all restrictions, asserting a commitment to principles of free expression. ${ }^{13}$ The debates stretched back to long-standing information strategies of West and East, and the framing of political ideologies in the specific context of the free flow of information.

The result of this conflict was failure to pass a binding international treaty on the regulation of direct broadcast satellites. Rather, in 1982, the UN General Assembly

Communication (Kaarle Nordenstreng \& Herbert I. Schiller eds., Ablex Publishing 1979); Jon T. Powell, International Broadcasting by Satellite: Issues of Regulation, Barriers to Communication (Quorum Books 1985).

9 Nuttall, supra note 6, at 394 (describing UN's creation of the Committee on the Peaceful Uses of Outer Space ("COPUOS") in 1958 to acknowledge "the international challenges that space exploration [and satellite communications] could present" and the committee's focus "on developing workable international standards, policy, and law that $\mathrm{t}[\mathrm{ook}]$ into account these new and developing challenges and their potential threat to international peace").

10 Alexandra M. Field, "INTELSAT at a Crossroads," 25 Law E Pol'y Int'l Bus. 1335 (1994).

1 U.N. GAOR, Comm. on the Peaceful Uses of Outer Space, Working Group On Direct Broadcast Satellites, "Report of the Second Session of the Working Group," 77 U.N. Doc. A/AC.105/66 (Aug. 12, 1969); see also U.N. GAOR Comm. on Peaceful Uses of Outer Space, "Broadcasting from Satellites, Working Paper Submitted by France to the Second Session of the Working Group on Direct Broadcast Satellites," 32-34, U.N. Doc. A/AC.105/PV.62 (June 30, 1969) (discussing Soviet position); Marika N. Taishoff, State Responsibility and the Direct Broadcast Satellite 34 (Pinter 1987) (describing Soviet fear of harmful propaganda).

12 See, e.g., Thomas L. McPhail, Electronic Colonialism: The Future of International Broadcasting and Communication 162 (Sage Publications 1987); Seán Ó. Siochrú and Bruce Girard, Global Media Governance: A Beginner's Guide 77 (Rowman \& Littlefield 2002).

13 See Frank Stanton, "Will they Stop our Satellites," N.Y. Times, Oct. 22, 1972, at D23; see also Nuttall, supra note 6 (discussing the United States' ardent support of the free flow of information and objection to virtually any interference with the right to impart information through any media form). 
adopted Resolution 37/92, Principles Governing the Use by States of Artificial Earth Satellites for International Direct Television Broadcasting. ${ }^{14}$ The explicit principle of requiring "prior consent" of the receiving countries was abandoned,,$^{15}$ but paragraph 8 of the nonbinding document provided "States should bear international responsibility for activities in the field of international direct television broadcasting by satellite carried out by them or under their jurisdiction." ${ }^{\prime 16}$ This reflected the alternative approach developed during the UN and UNESCO debates: a set of internationally agreed-on standards with the originating country being responsible for ensuring that no signal emanating from its territory would violate such standards, including those related to hate speech norms. ${ }^{17}$

As we shall see, the basic issues that guided national strategies in the UN debate continue to guide decisions concerning satellite communications today. The prior consent principle - granting that a state, even in the face of the right of an individual to receive and impart information, ${ }^{18}$ should have some say over the receipt of satellite signals within its borders - lurks. So too does the alternative principle, namely that there should be common standards (global, regional, or national) determining the content of what is transmitted or received using satellite platforms. These approaches exist as artifacts that find their way into contemporary actions and debates, albeit not as universal principles and very seldom with reference to their

14 G.A. Res. 2916, U.N. GAOR, 37th Sess., Supp. No. 92, 10oth meeting, U.N. Doc A/Res/37/92 (1982), http://www.un.org/documents/ga/res/37/a37rog2.htm (107 countries voted for the resolution, 13 voted against, and 13 abstained); see also Nuttall, supra note 6, at 395 ("Of the declarations of principles proposed by COPUOS and adopted by the United Nations, the Principles Governing the Use by States of Artificial Earth Satellites for International Direct Television Broadcasting [Principles on TV Broadcasting] provides the most focused look at the potential influence the United Nations expected satellite broadcasts to exert across international boundaries.").

15 See G.A. Res. 2916, supra note 14. Section J of the Resolution concerns "Consultations and agreements between States." Paragraph 13 reads: "A State which intends to establish or authorize the establishment of an international direct television broadcasting satellite service shall without delay notify the proposed receiving State or States of such intention and shall promptly enter into consultation with any of those States which so requests." Paragraph 14 reads: "An international direct television broadcasting satellite service shall only be established after the conditions set forth in paragraph 13 above have been met and on the basis of agreement and/or agreements in conformity with the relevant instruments of International Telecommunication Union and in accordance with these principles."

16 Id. at 98.

17 See Comm. on the Peaceful Uses of Outer Space, Legal Subcomm. Rep. on its 17th Sess., Annex 2, at 6, U.N. Doc. A/AC.105/218 (1978) (containing draft principles on direct television broadcasting). There was also an effort to encourage consultation: "For that purpose a State which proposes to establish or authorize the establishment of a direct television broadcasting service by means of artificial earth satellites specifically directed at a foreign State shall without delay notify that State of such intention and shall promptly enter into consultations with that State if the latter so requests." Id.

18 See International Covenant on Civil and Political Rights, art. 19(2), Dec. 16, 1966, 999 U.N.T.S. 171 ("Everyone shall have the right to freedom of expression; this right shall include freedom to seek, receive and impart information and ideas of all kinds, regardless of frontiers, either orally, in writing or in print, in the form of art, or through any other media of his choice."). 
historical antecedents. ${ }^{19}$ As one way to look at emerging patterns, one could say that in the absence of an agreed international approach, there are states that have adapted some versions of these principles, coming as close to a prior-consent principle or to the standards-related alternative as they technologically and politically can.

\section{III. “INFORMAL" GOVERNANCE AND INFLUENCE}

By and large, prior to the end of the 199os and 9/11, the lack of an overarching international system to govern the distribution of satellite programming was of little significance. ${ }^{20}$ Global players had not, as part of their communications strategy, fixed on transnational satellite programming, although some such efforts were nascent. Evangelical religious groups had begun to show the effectiveness of transnational broadcasting to affect allegiances. ${ }^{21}$ Diasporic movements began to find the technology hospitable, followed by states seeking to link more closely with their nonresident populations. One such case involving the Kurdish community - and MED-TV, discussed later in the chapter - raised the major issues of how a set of focused satellite signals could reinforce a national identity among a geographically dispersed group, and what dangers that might pose to territorial integrity. Problems of regulation remained in the background because authoritarian countries could ban satellite dishes or otherwise control the receipt of information. To the extent that there were transnational broadcasting issues of political moment, they involved the residual short-wave radio efforts of the Cold War. These diminished in significance during the 1990s, with a few idiosyncratic and intense exceptions such as Radio Marti and Radio Free Asia.

Then, with the founding and broadcasting of Al Jazeera in $1996^{22}$ and the NATO bombing campaign of 1999 (and with it a focus on the effort of Serbia to reach Serbians worldwide), the regional and global political impact of satellite transmissions began to attract renewed attention. As a result, internationally, states over the last

19 See Nuttall, supra note 6, at 404 (noting that "advocates of economic growth that support the expansion of the satellite market to promote competition" view regulation as necessary "to transform the telecommunications markets from monopolies into freely competing markets").

20 See John Tusa, "International Satellite Television - Good Neighbor or Global Intruder?,"7 Eur. Bus. J. 45 (1995) (discussing insufficiently developed satellite networks, in which numerous major players today "were scarcely in operation, their impact on societies and world events not yet fully felt or clearly demonstrated").

${ }^{21}$ See Michael Serazio, "Media Power, Politics and Proselytizing: The Global Gospel of American Christian Broadcasting," J. Media and Religion (2006), available at http://www.global.asc.upenn.edu/ docs/GlobalGospel.pdf (discussing the soft-power implications of American Christian broadcasting as it competes in the international marketplace for loyalties); see also Michael Serazio, "Geopolitical Proselytizing in the Marketplace for Loyalties: Rethinking the Global Gospel of American Christian Broadcasting," Paper presented at the annual meeting of the NCA 94th Annual Convention, San Diego, CA (Nov. 21, 2008).

22 Marc Lynch, Voices of the New Arab Public: Iraq, Al-Jazeera, and Middle East Politics Today (Columbia University Press 2006). 
decade have begun groping again for some accommodation with the issues and positions put forward in the UN debate of the 1970s. There is not (and most likely never will be) an international agreement that involves the prior consent approach or a set of enforceable international standards. But unilaterally, bilaterally, and multilaterally, states will seek similar considerations, where they consider it important. And, frequently, the efforts to do so will be informal, nonobvious, almost impermeable. Decisions will be pragmatic (with some recognition of standards and obligations of speech-related human rights). Inferring from past experience, the justification for these formal and informal efforts include maintaining a balance of loyalties in the receiving country; protecting the business status quo of video providers; decreasing "terrorist" related programming; and maintaining standards of morality. The efforts deal with modes of production, transmission, and reception.

This section uses particular cases to demonstrate how these actions reflect the communications goals of the sender, and how restrictions reflect the counterstrategy of the receiving states.

\section{A. MED-TV}

The case of MED-TV was one of the first in which the multilateral and informal aspects of satellite regulation significantly surfaced and the complexity of arrangements came to the fore. In 1994, MED-TV, a satellite service targeting Kurdish populations worldwide, was granted a ten-year license by the United Kingdom's Independent Television Commission (the "ITC"). ${ }^{23}$ MED-TV especially sought to reach Kurdish minorities in Turkey, Iran, and Iraq. The United Kingdom was its locus of licensing because it was "established"24 there, but its programming was produced in large part in Belgium. To some, the satellite feed was a culturally enriching mix of news, entertainment, and education aimed at a historically diasporic community of 35 million people engaged in rediscovering and redefining Kurdish nationhood and reaffirming its language and culture. Naomi Sakr captured this view, calling MED-TV a "kind of Kurdistan in space," ${ }^{25}$ as it provided a culturally unifying function despite the lack of a Kurdish homeland or single territorial base. In sharp contrast, Turkish officials claimed that MED-TV was the media arm of the PKK, the separatist Kurdish force that has been engaged in armed conflict with Turkish government troops and is considered by Turkey to be a significant threat to

23 Which, before being merged into a new entity, OFCOM, regulated commercial TV broadcasts in the United Kingdom (whether terrestrial or satellite). Indeed, the United Kingdom became home to a variety of satellite services seeking to reach groups or populations abroad and operate with the legitimization of a British license.

24 The organization "established" itself in the United Kingdom, a technical term that meant that they were qualified to receive a license from the UK's Independent Television Commission.

25 Naomi Sakr, Satellite Realms: Transnational Television, Globalization and the Middle East 62 (I. B. Taurus 2001). 
the integrity and unity of the country. ${ }^{26}$ For Turkey, MED-TV was a foreign intrusion, disturbing the local forms of regulation, and seeking to foment instability and violence. The Turkish government contended that MED-TV was fostering extremist claims and stirring up animosity among the Turkish population.

The Turkish government sought to suppress the receipt of the channels, for example, by attempting to ban the purchase and mounting of satellite dishes that could obtain the signals. ${ }^{27}$ When this effort failed, Turkey sought to deny MED-TV leasing rights on government-controlled transponders on Eutelsat and mounted a campaign to pressure the British government to withdraw MED-TV's license. ${ }^{28}$

The location and ownership of the transponders on the Eutelsat system that were used by MED-TV were politically significant. Under Eutelsat's internal rules, the satellite's transponders were (loosely) controlled by public agencies; the states that controlled those agencies had good bilateral relations with Turkey. Stories were told of MED-TV securing time on a Slovakian-controlled slot on a satellite only to have the Turkish Foreign Minister obtain a cancelation through bilateral discussions. MED-TV was unceremoniously bounced from various transponders on Eutelsat and its contracts for access canceled or left to expire. One of the features of such informal negotiations and decisions was the absence of any requirement that the reasons behind the decision be published or justified.

One solace, an anchor, as it were, was MED-TV's British license. Whatever the station's political goals, the choice of a relatively secure legal and political system that would govern the delivery of its information seemed to be one of MED-TV's most important achievements and was a vital part of the strategy for obtaining transponder space to reach the relevant audience. Its establishment in the United Kingdom resulted in MED-TV's being subject to the ITC's content standards. Receiving a British permit allowed MED-TV to claim that it met those standards. This was seen as a means for increasing the chances that its programming would be subject only to legal, as opposed to extralegal, constraints. ${ }^{29}$ Thus, Turkish officials

26 See "Turkey Calls on USA to End MED-TV Broadcasts," BBC Summary of World Broadcasts, Aug. 30, 1996; "MED-TV Off the Air After UK, Belgian Police Raids," BBC Summary of World Broadcasts, Sep. 27, 1996; "Turkish Premier Discusses MED-TV With Tony Blair," BBC Summary of World Broadcasts, Dec. 19, 1997; Amir Hassanpour, "Med-TV, Britain, and the Turkish State: A Stateless Nation's Quest for Sovereignty in the Sky" (unpublished paper presented at the Freie Universitat Berlin, Nov. 7, 1995).

27 For example, its transmission was originally on a satellite that directed its signal from a different location from the more commonly viewed Eutelsat satellites. MED-TV viewers had to turn their satellite dishes in a different direction from those receiving the Eutelsat original satellite, one that carried traditional Turkish entertainment channel services. The authorities could see the difference in the attitude of the dish and could use that information to harass the MED-TV viewers. To protect its viewers, MED-TV had to shift, therefore, to the more commonly viewed bird in the sky.

28 Peter Feuilherade, "Med-TV: 'Kurdistan in the Sky'," BBC News (Mar. 23, 1999), available at http: //news.bbc.co.uk/2/hi/world/monitoring/280616.stm.

29 See Price, supra note 1 ("At the danger of pushing the metaphor too far, the MED-TV decision to obtain a license in the United Kingdom could be perceived as a rough equivalent of flying the British flag on the main mast."). 
mounted an extensive campaign to pressure the British government to withdraw MED-TV's license and close down the producer. As part of this campaign, the Turkish government contended, with some informal proffer of evidence, that MEDTV was a "political organization" linked to the PKK and therefore, under UK legislation, precluded from obtaining a British license.

In February 1998, the ITC, charged with supervision of licensed entities in Britain, penalized MED-TV for three broadcasts, for a total fine of approximately $\$ 150,000.3^{\circ}$ According to the Commission, despite formal warnings, MED-TV violated the impartiality requirements of ITC's programming code. In one breach, according to the ITC, a " 40 minute long programme consisted entirely of a political rally organized by the PKK." The violation was that " $[n]$ o context was supplied and there was no balancing material." In a second breach of impartiality requirements, MED-TV "seemingly endorsed" the on-camera condemnation of a U.S. list of terrorist organizations that included the PKK. A third transgression involved "'personal comments' from a MED-TV journalist in the field, namely a description of the more progovernment Kurdish Democratic Party as "treacherous and murderous." Finally, in 1999, the ITC withdrew MED-TV's license, finding that the station had too often violated standards of objectivity and impartiality. At the time, Sir Robin Biggam, the ITC's chair, defended the decision, using an argument that was not within the terms of the decision itself: "Whatever sympathy there may be in the United Kingdom for the Kurdish people, it is not in the public interest to have any broadcaster use the UK as a platform for broadcasts which incite people to violence." $3^{1}$

Soon thereafter, MED-TV closed down. ${ }^{22}$ The project, however, was only temporarily blocked; given the complex, robust, and many-sourced bazaar for transponder rentals, versions have cropped up, albeit always and continuously subject to pressures on national hosts, in France and elsewhere, to curtail the service. 33 Despite

30 This history is recounted in Monroe E. Price, "What Price Fairness?" 12 Media Studs. J. 82 (1998), from which this paragraph draws.

${ }^{11}$ See "UK Regulator Revokes Kurdish Med TV's License," BBC News (Apr. 23, 299), available at http://news.bbc.co.uk/2/hi/world/monitoring/326883.stm("Whatever sympathy there may be in the United Kingdom for the Kurdish people, it is not in the public interest to have any broadcaster use the UK as a platform for broadcasts which incite people to violence. Med TV have been given many opportunities to be a peaceful voice for their community; to allow them to continue broadcasting after such serious breaches would be to condone the misuse of the UK's system for licensing broadcasters.") (quoting ITC chair Sir Robin Biggam).

32 David Romano, The Kurdish Nationalist Movement: Opportunity, Mobilization, and Identity 157 (Cambridge University Press 2006).

33 See "New Kurdish TV Station Medya TV," BBC Monitoring (July 30, 1999 to Aug. 3, 1999). A successor, Medya-TV, opened in the summer of 1999, but under different legal circumstances:

A new Paris-based Kurdish satellite television station identifying itself as Medya TV has been observed since 3 oth Jul. It broadcasts via the Eutelsat Hot Bird 4 satellite at 13 degrees east (10853 MHz vertical polarization, audio subcarrier $6.65 \mathrm{MHz}$ ). This transponder also carries Kurdish and Christian programming from the UK-based CTV (Cultural TV). . . News bulletins formerly carried on CTV appear to have transferred to Medya TV along with some of the presenters.... Medya TV carried a live relay of its official launch ceremony in Paris. The 
the legal efforts, MED-TV and its successors have persisted in finding ways to deliver some content to its dispersed audiences.

\section{B. Islah}

The case of MED-TV is atypical because of the formality of the proceedings involving its content. Far more typical was the informal regulation of content in the instance of Islah or Reform Radio. ${ }^{34}$ The Islah case involved Abdulzazis Alkhamis, former head of the London-based Saudi Center for Human Rights. As part of a strategy of dissenting civil society, Alkhamis sought to open up a space for speech in Saudi Arabia that arguably promoted greater public participation and democracy (although there could be other characterizations of the content). ${ }^{35}$ In 2002, he contacted Saad $\mathrm{Al} \mathrm{Fagih,} \mathrm{head} \mathrm{of} \mathrm{the} \mathrm{Movement} \mathrm{for} \mathrm{Islamic} \mathrm{Reform} \mathrm{in} \mathrm{Arabia,} \mathrm{as} \mathrm{a} \mathrm{potential} \mathrm{partner}$ for a radio channel they named "Islah," or "Reform," Radio. ${ }^{36}$ (To illustrate the tenuousness of characterizations, Al Fagih was first referred to in the Wall Street Journal as a "dissident," but later described by the U.S. government with the harsh and conclusory label "terrorist" or "aider and abettor" of terrorists.) With a plan to use media to reach into Saudi Arabia with a "democracy"-related message, the next question was a technical one: How to have a signal reach Saudi Arabia and become available to Saudis so that Alkhamis and Al Fagih's message could be heard. They searched out individuals who were experienced in helping outside groups,

ceremony was held in a hall with the Medya logo depicted in laser lights as the stage backdrop. Two large screens on either side of the stage showed the musicians and the announcers, who spoke in Kurdish. What appeared to be a message marking the launching of the station by Kurdish National Congress President Serif Canli was carried at 1710 GMT. It was followed by a similar message in Kurdish from Yasar Kaya, president of the Kurdish parliament-in-exile.

Id. Medya TV's license was revoked by the French authorities on February 13, 2004. "Kurdish Medya TV Shuts Down," Clandestine Radio Watch (Feb. 13, 2004), available at http://www.clandestineradio. $\mathrm{com} / \mathrm{crw} /$ news. php?id=211\&stn $=684 \&$ news $=318$.

34 See Movement of Islamic Reform in Arabia (MIRA), available at http://www.islah.info/index.php?/ english/emppi1/.

35 See David Crawford, "A Battle for Ears and Minds: As Technology Gives New Voice to Dissent, a Saudi Vies to Be Heard," Wall St. J., Feb. 4, 2004 (discussing Islah's claimed purposes and innovative techniques). The BBC reported:

Radio stations run by opposition groups are a rare occurrence in the Arab world, and the launch marks a dramatic breakthrough in a region where public broadcasting is tightly regulated by governments. The new satellite station Sawt Al-Islah - which means Voice of Reform - is using the latest internet technology to help disgruntled Saudis voice their criticism of the royal family. A spokesman for the Movement for Islamic Reform In Arabia told the BBC that by using an internet phone service - known as Paltalk - listeners can take part in the programme and say what they like without risking arrest or harassment. Saad al-Fagih said the bulk of the station's schedule was talk shows. The topics discussed, he said, included lack of transparency in the Saudi system, corruption, poverty and failure to implement Islamic law.

Magdi Abdelhadi, "Saudi opposition gets radio voice," BBC News - World Edition (Dec. 9, 2002), available at http://news.bbc.co.uk/2/hi/middle_east/2560313.stm.

36 Crawford, supra note 35. 
including church groups, state-sponsored international broadcasters, and splinter political groups, gain access across borders. They hired Ludo Maes, a Belgian shortwave specialist, who helped Islah gain access to short-wave transmitters located in Lithuania that were left over from short-wave broadcasts during the Cold War. ${ }^{37}$ With Maes' counsel, Islah also contracted to be broadcast over the Hotbird satellite, owned by Eutelsat. Deutsche Telekom was the lessee of bandwidth on the satellite and provided Islah uplink facilities. Reform Radio began broadcasting over satellite and short-wave in December 2002, encouraging listeners "to speak out against corruption and for a moderate Islamic government in Saudi Arabia." $3^{8}$

Intervention and difficulty began almost immediately. First, the short-wave signal was jammed by a powerful opposing transmitter (set up to transmit on the same frequency). 39 In addition, Maes received a formal communication from a lawyer representing the Saudi Embassy in Belgium threatening legal action to halt the broadcasts, accusing the project of inciting terrorism through the broadcasting of propaganda. With short-wave jammed, Islah relied on its satellite broadcasts (with the shortcoming that the radio broadcasts only could be received on Saudi television sets). For this and other reasons, Reform Radio established a satellite television station and set up an uplink in Croatia. $4^{\circ}$ David Crawford continues the story:

A week later, the phone rang at the Usingen Earth Station near Frankfurt, where T-Systems, a Deutsche Telekom subsidiary, controls and monitors television, radio and data beamed to satellites. On the line was an anonymous caller. "Stop broadcasting Reform Radio or we will jam you," he said, according to someone involved in the incident. About the same time, a powerful jamming beam turned the video monitor in the office to static.

The jamming affected five TV programs broadcast via the same transponder, including several small commercial channels. When Deutsche Telekom stopped

37 See National Association of Shortwave Broadcasters, Inc., http://www.shortwave.org/ (demonstrating some of the variety of users, though emphasizing religious broadcasters); Clandestine Radio Stations broadcasting to Kurdistan, http://www.schoechi.de/cl-kur.html (describing 2005 efforts by Maes relating to Kurdistan TDP Shortwave Transmitter Airtime QSL-Cards); http://www.airtime. be/qsl.html (Maes' Transmitter Documentation Project); "hard-core-dx info" (Oct. 21, 2001), http: //www.hard-core-dx.com/archives/octzoo1.html ("My hunch, and it is only that, about the reason for TDP secrecy on actual transmitter sites, is that some of this business is under-the-table, i.e. technicians at certain under-used sites are paid to put the programs on the air without full knowledge or authorization by the governmental agencies owning them,' writes Glenn Hauser in an issue of DX Listeners Digest. Ludo Maes has responded with dismay to these 'lies and serious accusations', adding: 'Don't we have a right for not publishing transmitter sites?"'); TDP Clandestine and Opposition Shortwave Radio Stations and International Broadcasters, http://www.shortwave.be/cla.html (listing opposition stations using short wave).

$3^{8}$ Crawford, supra note 35 .

39 The ability to jam short-wave signals is far greater than the ability to jam satellite signals.

$4^{\circ}$ See Crawford, supra note 35 ("Mr. Fagih, liberal by Saudi standards but still orthodox on most religious issues, prohibited music for moral reasons. Mr. Alkhamis had no budget for video programming. Instead, he broadcast a picture of the Reform logo, along with text information scrolling across the screen. The audio was from the radio broadcast."). 
broadcasting Reform briefly, the jamming was stopped. A new anonymous phone call would then warn Deutsche Telekom not to resume broadcasting. On Oct. 25, Deutsche Telekom canceled its contract with Reform Radio. ${ }^{41}$

But this was hardly the end of the station's difficulties. In December 2004, the United States added Al Fagih to the State Department's list of terrorists; shortly thereafter, Al-Fagih was put on the UN's Consolidated List of terrorists. The Movement for Islamic Reform in Arabia was added to the State Department's list in July 2005.42

For present purposes, the importance of this story is the variety of informal arrangements implicated in the contested effort by these interests to enter the Saudi "market for loyalties." To fathom what occurred, it is important to understand the structure of access to short-wave and satellite transponders, the technical aspects of jamming; the modes of informal threats to intermediaries, the techniques of states bringing pressure to bear on other states to alter modes of diffusion, the modes of affecting financing (through terror lists and other means), and the interrelationship of technologies. There are elements that are difficult to retrieve, including how foreign dissenting channels are actually received, how reception fits in with constraints and policing that occurs in Saudi Arabia, and Our current understanding, for example, what modes of formal and informal surveillance serve as barriers to reception.

\section{Al Zawraa}

The case of $\mathrm{Al}$ Zawraa provides additional insights into the questions of informal pressure, this time involving a state that is neither the receiver nor the sender of the signal, namely the United States. Al Zawraa started as a broadcast channel in Iraq, with an audience-pleasing entertainment format. Owned by Mishan Al Jaburi, leader of the Sunni Arab Front for Reconciliation and Liberation, the channel over time became more politicized, reflecting the owner's decision to run for the Iraqi parliament. More importantly, it morphed into what Ibrahim Al Marashi and others have called insurrectionist television, ${ }^{33}$ playing, among other things, repeated videos of jihadist bombings with footage of attacks against multinational forces. In November 2006, the Iraqi government ordered the station to be terminated and its offices in Iraq closed on charges of "inciting violence and murder." 44

$4^{1} \quad$ Id.

42 "U.S. Treasury Designates Two Individuals with Ties to al Qaida, UBL Former BIF Leader and al-Qaida Associate Named Under E.O. 13224” (Dec. 21, 2004) (press release), available at http://www. treasury.gov/press-center/press-releases/Pages/js2164.aspx.

43 Ibrahim Al Marashi, “The Dynamics of Iraq's Media: Ethno-Sectarian Violence, Political Islam, Public Advocacy, and Globalization,” 25 Cardozo Arts \& Ent. L.J. 95 (2007).

44 Andy Sennitt, “Iraq: US Blacklists Al-Zawraa TV," BBC Monitoring (Jan. 10, 2008), available at http://blogs.rnw.nl/medianetwork/iraq-us-blacklists-al-zawraa-tv. 
Banned from using transmitters in Iraq, $\mathrm{Al}$ Jaburi staked his future on a satellite strategy, leasing channels on Egyptian-owned Nilesat. The channel's campaign against the U.S.-supported Iraqi government intensified - broadcasting "a blend of pro-insurgent propaganda, video clips of attacks on Coalition forces and calls for violence against Iraqi Shi" is and the Iraqi government" 45 and "audio messages from the Islamic Army of Iraq, an insurgent group dominated by the Iraqi Ba'th Party loyal to former president Saddam Husayn." ${ }^{46}$ An influential American blogger described showing the Al Zawraa feed to U.S. soldiers and Iraqis:

The soldiers and terps [(interpreters)] described the meaning of the images, music and voiceovers. There were songs about the Iraqi "victims" of the "U.S. occupiers." The violence in Iraq is squarely placed on the shoulders of the Americans. The images include destroyed mosques, dead women and children, women weeping of the death of their family, bloodstained floors, the destruction of U.S. humvees and armored vehicles, and insurgents firing mortars, RPGs, rockets and AK-47s. Juba, the mythical Iraqi sniper, was featured prominently (the Iraqi soldiers believe he is a composite of multiple snipers.). The "mujahideen" are portrayed as "freedom fighters," and are seen going through "boot camp training." Attacks from across the country were shown, including in Abu Ghraib, Ramadi, Fallujah, Baiji, Baghdad and elsewhere. The soldiers are seasoned veterans from the 1st Iraqi Army Division, and have served throughout Iraq. Most of the footage was popular, rehashed videos widely distributed on the Internet and in jihadi forums. I recognized many of the videos. The soldiers were angry at the images before them. "They destroyed my country," said Staff Sergeant Riad."47

The U.S. government began discussions with the Egyptian government to terminate the Al Zawraa transponder lease on Nilesat. Closing Al-Zawraa became a preferred alternative for Iraqi and U.S. officials. A report on Cairo's Al-Misriyun newspaper Web site in early 2007 said the U.S. ambassador in Cairo had asked Egyptian Information Minister Anas al-Fiqi to

pull the plug on the channel, on the pretext that it constituted the last weapon in the hands of those he described as the Sunni "rebels" in Iraq. The minister, however, declined to respond to the ambassador's request initially, affirming that the broadcasting of the channel was purely a business transaction that had nothing to do with politics. The operational costs of the Egyptian satellite required the

45 Peter Feuilherade, "Egypt Row Brews Over Iraqi Sunni Channel Al-Zawraa on Nilesat," BBC Monitoring, Jan. 9, 2007.

$4^{6} \mathrm{Id}$.

47 Bill Roggio, "Al-Zawraa: Muj TV," The Long War Journal (Dec. 10, 2006), http://www.longwarjournal. org/archives/2006/12/muj_tv.php. For Al Jaburi's response to Roggio's article, see Bill Roggio, "AlZawraa Responds to Muj TV," The Long War Journal (Dec. 25, 2006), http://www.longwarjournal.org/ archives/2006/12/alzawraa_responds_to.php (demonstrating Aljabouri’s efforts to distinguish al-Zawraa from al Qaeda). 
renting of unoccupied channels. But threats made by supporters of the Shi'i AlMahdi Army affiliated with Muqtada al-Sadr to attack and kill members of the Egyptian diplomatic mission in Baghdad constituted pressure that drove Egypt to backtrack on its stand in this regard. $4^{8}$

There were dissenting voices (albeit not predominantly on free speech grounds):

This is [a] major dilemma in the modern age of information warfare. On [the] one hand, programs like al-Zawraa provide ready and effective propaganda and recruiting material for the insurgency and al Qaeda, while demoralizing both Western and Middle Eastern allies. On the other, the intelligence gleaned from these operations is deemed too valuable to turn off the tap. ${ }^{49}$

Superficially, Nilesat officials resisted the pressure and indicated that carriage was merely a contractual matter. The Nilesat chair was reported as saying, in Al-Misri Al-Yawm, that "satellites do not monitor the channels they are carrying. Accordingly, the Egyptian satellite should not be part of the dispute regarding the channel. It is the right of whoever is hurt by the material broadcast by Al-Zawraa to respond through their channels or media."50

With the threat of being ejected from Nilesat, Al Jaburi claimed the station soon would be carried "on three satellites from European countries." ${ }^{11}$ He refrained from identifying the satellites "because we are really afraid of American pressures. But after we transmit [from Europe] there will be no fear anymore because we will be on the air." ${ }^{2}$ By late January, Al-Zawraa was observed to be broadcasting via the Saudiowned Arabsat and France-based Eutelsat. ${ }^{53}$ In February, the Nilesat transmission was closed after Nilesat accused the station of "interference" with other channels; 54 in April, the French regulator required Eutelsat to stop transmission, claiming that the station's broadcasting of propaganda was in breach of the September 30, 1986 law prohibiting stations from incitement to hate and violence for reasons of religion or nationality, and the 1881 law of freedom of the press. 55

$4^{8}$ Feuilherade, supra note 45.

49 Roggio, supra note 47.

$5^{\circ}$ Feuilherade, supra note 45 .

${ }^{11}$ Lawrence Pintak, "War of Ideas: Insurgent Channel Coming to a Satellite Near You," USC Center on Public Diplomacy (Jan. 10, 2007), http://uscpublicdiplomacy.com/index.php/newsroom/pdblogdetail/o7onı_war_of_ideas_insurgent_channel_coming_to_a_satellite_near_you/.

$5^{2} \mathrm{Id}$.

53 See "Iraqi Sunni Al-Zawraa TV now carried on Saudi-based Arabsat," BBC Monitoring (Jan. 26, 2007); "Iraqi Sunni Al-Zawraa TV now broadcasting on European satellite," BBC Monitoring (Jan. 31, 2007).

54 "Egypt Takes Militant Iraqi Channel Off Air," Daily Star (Feb. 26, 2007), http://www.dailystar.com. lb/article.asp?edition_id $=10 \&$ categ_id $=2 \&$ article_id $=79858$.

55 Décision n 2007-293 du 3 avril 2007 mettant en demeure la société Eutelsat SA, [Decision No. 2007293 of Apr. 3, 2007 giving notice to the company Eutelsat SA] available at http://www.legifrance.gouv. fr/affichTexte.do?cidTexte=JORFTEXToooooo822549\&dateTexte $=$. 
Finally, on January 9, 2008, Al Jaburi and Al Zawraa were placed on the U.S. sanctions list, precluded from any financial transactions with U.S. citizens or companies. According to Intelligence Online:

On Jan. 9, the U.S. Treasury published a list of several individuals and entities subject to financial sanctions for backing Iraqi insurgents. Among them was the Iraqi politician Misham Al Jabouri and the satellite television channel he runs out of Damascus, Al Zawraa. Since October, 2006, the station continually ran messages and video clips shot by Sunni Baa'thist militia in their fight against American troops in Iraq....

Starting from last spring, only the Pan-Arab operator Arabsat, which is majorityowned by Saudi Arabia, continued to broadcast Al Zawraa via its Badrz and Arabsat ${ }_{2} B$ satellites. The State Department complained in vain to Riyadh before opting for a more aggressive strategy. In March, the frequency on which Al Zawraa broadcasted on Badr 3 (11747 MHz) was constantly jammed, forcing the station to cease its programs before switching to another frequency $(11765 \mathrm{MHz})$.

That manoeuvre won a reprieve for Al Zawraa for several months but the offensive resumed in July. Starting from July 7 , reception of the station in Iraq became spotty and the channel remained unavailable for days at a time. On July $30, \mathrm{Al}$ Zawraa finally ended broadcasting in Iraq. The channel sent several messages to its audience to say its signals were jammed. On July 24, the Sunni web forum Hanin.net announced that one of the channel's clandestine stations in Iraq had been bombed and that most of its employees were killed..$^{6}$

The level of official frustration with $\mathrm{Al}$ Zawraa, with its inability to locate the production facilities, and the complex efforts to deny the channel access to distribution facilities, had ended with this step. The Al Zawraa case could be seen as a harbinger of the Arab Satellite Broadcast Charter that I discuss in the conclusion.

\section{Al Manar}

I contrast the preceding examples with the very complex story of $\mathrm{Al} \mathrm{Manar},{ }^{57}$ the Hezbollah-related broadcasting station based in Lebanon, which was expanded to include a satellite distribution channel targeted at Arabic-speaking populations throughout Europe and beyond..$^{8}$ In this case, a much more formal process of

\footnotetext{
56 “U.S. Pulls Plug on Insurgent TV; Baghdad," Intelligence Online (Jan. 17, 2008).

57 Al Manar TV, http://www.almanar.com.lb/NewsSite/News.aspx?language=en.

$5^{8}$ A statement from the European Union noted:
}

In 1991, shortly after Hezbollah actively entered the Lebanese political scene, Al Manar was launched as a small terrestrial station. Although legally registered as the Lebanese Media Group Company in 1997, Al Manar has belonged to Hezbollah culturally and politically since its inception. Today, the terrestrial station can reach Lebanon in its entirety and broadcasts programming eighteen hours daily.

Moreover, Al Manar's satellite station, launched in 2000, transmits twenty-four hours a day, reaching the entire Arab world and the rest of the globe through several major satellite providers. One of the satellite providers which has transmitted Al Manar has been the French satellite Hot Bird 4, owned by the Eutelsat Satellite organization. 
regulation began to emerge. The production and distribution of programming was a critical element in Hezbollah's constituency building within Lebanon and provided a link to interested audiences in Europe and elsewhere. To reach audiences in Europe, Al Manar deployed on Eutelsat, but almost immediately faced resistance, including from groups that objected to its statements concerning Jews and Israel. ${ }^{59}$ In late 2003 , Al Manar was accused, in France, of distributing anti-Semitic programming in violation of French standards. ${ }^{60}$ The introduction of the satellite channel into Europe forced the French state into the role of umpire between conflicting interests.

Because Al Manar originated outside of France, and outside of the EU, it presented a jurisdictional and governance crisis. The question arose (and here, it is not necessary to take a position on the nature of the programming) whether the French regulatory agency, the Conseil Supérieur de l'Audiovisuel (CSA), had authority to take action. In February 2004, the CSA and Paris-based Eutelsat entered into an agreement regarding the oversight of satellite broadcasters from outside the EU not licensed by an EU member country. ${ }^{61}$

A Eutelsat press release stated that the organization shared the CSA's "indignation expressed on [the] broadcasting of racist programmes," ${ }^{2}$ but also made it clear that the carrier had no right to censure the programming it carried absent a regulatory requirement that it do so. The problem was a typical one involving satellite channels: There was no national license involved that would govern who had authority over the content of the channel. The CSA, on the other hand, took the position that because the channel was uplinked to Eutelsat, and Eutelsat was a French company,

"EU Rules and Principles on Hate Broadcasts: Frequently Asked Questions," Europa, http://europa.eu/rapid/pressReleasesAction.do? reference=MEMO/05/98\&format=HTML\&aged= o\&language $=\mathrm{EN} \&$ guiLanguage $=\mathrm{en}$.

59 See "U.S. Following French Lead in Banning Hezbollah Station," The America's Intelligence Wire, Dec. 17, 2004. A week after the French ban, the United States designated Al Manar a terrorist organization, and transmission into the U.S. was banned. The interaction between the informal and the formal in terms of government action is complex but useful to examine. For example, Al-Nour Radio, deemed a Hezbollah-controlled radio station, was named a "specially designated global terrorist entity," a harsher categorization than the Terrorist Exclusion List, along with Al-Manar TV, by the U.S. Department of the Treasury in March 2006. The designation had its intended consequences. It caused the Spanish Hispasat, GlobeCast American, and New Skies Satellite companies to terminate Al-Nour's broadcasting to South America via Hispasat, Asia via AsiaSat, and New Skies Satellite to Europe.

6o See U.S. Dep’t of State, Report on Global Anti-Semitism (2005), available at http://www.state.gov/ $\mathrm{g} / \mathrm{drl} / \mathrm{rls} / 40258 . h \mathrm{tm}$. The report discusses Israel's complaints and states that in November 2004, "AlManar, the Lebanon-based television network controlled by Hizballah featuring blatantly anti-Semitic material, obtained a limited 1-year satellite broadcast license from the French authorities. This was revoked shortly thereafter due to Al-Manar's continued transmission of anti-Semitic material." France subsequently banned Al Manar.

61 See "France: Eutelsat, Regulator Agree to Cooperate on Unlicensed Broadcasters," BBC Summary of Worldwide Broadcasts, Feb. 5, 2004.

62 "Cooperation Between Eutelsat and the CSA" (Feb. 3, 2004) (press release), available at http://www. eutelsat.com/news/pdf/2004/pro402.pdf. 
the broadcasts (or at least the satellite carrier) were within the CSA's jurisdiction under the EU's Television Without Frontiers directive.

To clarify this authority in anticipation of some concern over power, the CSA already successfully had applied to the public prosecutor, arguing that "[t]he transmission by the Al-Manar channel of thirty episodes of 'Diaspora' may have been seen as anti-Semitic." ${ }^{3}$ The CSA president highlighted the difficulties facing the agency when dealing with channels established outside the European Union which still fall under the competence of the French authorities. There were grave jurisdictional issues in engaging in action against satellite operators or their intermediaries through which these external channels were broadcast. The government had to deal with its own strategic concerns: its relationship to domestic communities, its historic relationship to Lebanon, and the convulsive nature of disputes within the Middle East as they found their way to Europe.

The CSA and Eutelsat began a policy of cooperation to check television channels transmitted by Eutelsat for their conformity to European legislation; the National Assembly adopted amendments allowing the CSA authority over operators of satellite networks, power to sanction Eutelsat, and authority to ask the Conseil d'Etat France's supreme administrative court - to order a carrier to cease transmission of a service where a breach of human dignity, the safeguard of public order, or the protection of minors was involved. ${ }^{64}$ Ultimately, by July 2004, the CSA requested the Conseil d'Etat to order Eutelsat to stop transmitting the station. According to the Agence France-Presse news agency, this followed the adoption of a new law on July 9 that gave the CSA new powers to ban satellite TV channels not subject to licensing. ${ }^{65}$ Even here, the CSA actions were a combination of direct regulation, informal negotiation, and "voluntary" action by Al Manar itself. For example, in November of that same year, the CSA granted Al Manar the right to operate in France as long as it abided by French law and did not incite hate or violence. But just four days later, the station aired a show that prompted new criticism, and on December 13, 2004, the Conseil d'Etat ordered Eutelsat to stop transmitting Al Manar within two days. ${ }^{66}$

63 See "France: Broadcast Regulator Explains Anti-Racist Policies," BBC Monitoring World Media (Mar. 3, 2004).

64 See French Prime Minister’s Office, "Prevailing Against Terrorism: White Paper on Domestic Security Against Terrorism," available at http://www.ambafrance-dk.org/IMG/pdf/livre_blanc_english.pdf (French Prime Minister's Office publication discussing its position regarding Al Manar and its subsequent effects to cooperate with European legislation to combat racism).

65 See "Analysis: French Ban on Al-Manar TV Sparks Diplomatic Row," BBC Monitoring Research, Aug. 17, 2004 .

66 The text of the July 9 ruling is available at http://legifrance.gouv.fr/affichTexte.do?cidTexte= JORFTEXTo00000439399. The text of the December 13 ruling is available at http://www.conseil-etat. fr/cde/node.php?articleid=1096. See also Elaine Sciolino, "A New French Headache: When Is Hate on TV Illegal?" N.Y. Times (Dec. 9, 2004). 


\section{TOWARD THE FUTURE}

Among the models for future treatment of these questions, the EU - in its post Al-Manar consciousness - presents a direction that is formal, regulatory, and bureaucratic. The consistent position on regulating satellite broadcasting within the EU has been that where a broadcast originates within the EU (which was not the case with $\mathrm{Al} \mathrm{Manar),} \mathrm{it} \mathrm{is} \mathrm{the} \mathrm{responsibility} \mathrm{of} \mathrm{the} \mathrm{Member} \mathrm{State,} \mathrm{the} \mathrm{so-called} \mathrm{"country}$ of origin," to regulate it. To this end, a series of practical criteria ("establishment" criteria in Article 2 of the Television Without Frontiers directive), for determining which Member State has jurisdiction. These criteria are:

- the location of the head office of the provider of services;

- the place where decisions on programming policy are usually taken;

- the place where the program to be broadcast to the public is finally mixed and processed; and

- the place where a significant proportion of the workforce required for the pursuit of the television broadcasting activity is located. ${ }^{67}$

An additional lens through which this debate can be seen involves a kind of conflict of laws analysis. For instance, in the EU, if a program is lawful in the Member State where it is established, then no other Member State can deny it entry. (There are specific exceptions to this rule, some of which - for example, looking more at the exclusive target audience of an offering - date from the 2007 amendments to the Television Without Frontiers Directive. $\left.{ }^{68}\right)$ It is the standard of the state of origin that determines whether a channel's programming passes muster. ${ }^{69}$

The Al Manar case was an intermediate step in terms of providing transparency in regulation and an effort to shape a systematic approach to satellite carried channels from outside the EU. Indeed, the reaction of the EU to the Al Manar case is the closest we have come to something that anticipates "global governance" or organized consideration of satellite-related delivery issues across many national boundaries. And it is not very close yet. If, as was the case with Al Manar, the satellite channel originates in a third country, outside the EU, different rules apply, according to the

${ }^{6} \mathrm{See}$ Directive 2007/65/EC of the European Parliament and of the Council of 11 December 2007, O.J. (L 332) 37, art. 2, \ 3 (amending Council Directive 89/552/EEC on the coordination of certain provisions laid down by law, regulation or administrative action in Member States concerning the pursuit of television broadcasting activities).

68 See "Analysis: French Ban on Al-Manar TV Sparks Diplomatic Row," supra note 65, at 31 (graph 34).

69 For more discussion on the country of origin approach, see Anna Herold, "Country of Origin Principle in the EU Market for Audiovisual Media Services: Consumer's Friend or Foe," 31 J. Consumer Policy 5 (2008). The debate over a new Audiovisual and Media Services Directive, which replaced the Television Without Frontiers Directive, partially concerned whether to shift, at least partially, from a country of origin to country of receipt approach. 
French precedent. Member States must ensure that such a broadcaster comply with the EU rules if:

- it uses a frequency granted by that Member State,

- it uses a satellite capacity appertaining to that Member State, or

- it uses a satellite up-link situated in that Member State. $7^{\circ}$

Because most TV channels from outside the EU broadcast in Europe using satellite capacities provided either by Eutelsat, which is based in France, or by Astra, which is based in Luxembourg, France and Luxembourg have jurisdiction over a large number of third-country programs received within the EU. During the French proceeding involving Al Manar, the European Commission worked with the French authorities to achieve an EU approach that could be applied to all similar cases. ${ }^{71}$ Where signals originating outside of the EU seek EU audiences (using satellites under the jurisdiction of individual Member States), the relevant authorities should block their diffusion (or at least alert the other Member States) if these incoming channels fail to meet EU standards.

In March 2005, after the Al Manar decision, EU officials recognized that difficulties would arise if it were only up to the particular states that had jurisdiction over satellite providers to police hate speech (or what might be generically called hate speech) issues. Better coordination among the states would be essential. The 2007 passage of the Audio Visual Media Services Directive, amending the Television Without Frontiers Directive, makes use of an uplink in a Member State a priority (after use of granted frequency)..$^{72}$ This distributes jurisdiction over more Member States. What is not yet clear is how many, if any, of the problematic channel providers have shifted uplink sites to take advantage of a different country's jurisdiction, or the extent to which more states will assert authority.

Another problem is presented by third-country broadcasts that can be seen in Europe because of satellite spillover from other countries - that is, where the channel originates outside the EU and the facility used (satellite, frequency, etc.) also is outside the Member State zone. These spillover effects are one reason why the cooperation of regulatory authorities within the $\mathrm{EU}$ is insufficient and must be complemented by cooperation with regulators from third countries (for example, the Mediterranean Regulators' Group).

Another perspective - one with the appearance of formality but with great elements of the pragmatic - arises from local efforts to control satellite signals distribution in the

70 See Directive 2007/65/EC, supra note 67, at 37, art. 2, 9 4.

${ }^{71}$ See "Conclusions, High-level Group of Regulatory Authorities in the Field of Broadcasting - Incitement to Hatred in Broadcasts Coming From Outside of the European Union," Europa Mar. 17, 2005, available at http://ec.europa.eu/avpolicy/docs/library/legal/conclusions_regulateurs/concl_reg_fin_en. pdf.

72 See also European Union Committee, "Television Without Frontiers?: Report with Evidence," $3 \mathrm{~d}$ sess. 2006-07, (Jan. 31, 2007), available at http://www.publications.parliament.uk/pa/ld200607/ldselect/ ldeucom/27/27.pdf. 
Middle East and to use hate speech and similar standards in the process. Most satellite channels viewed in the region are transmitted using transponders of two satellites, Nilesat and Arabsat, both of which are closely tied to regional governments. The management of the two satellites has varied in terms of the stringency of standards or the degree of control involved in determining what channels are transmitted. But as is true in most parts of the world, gaining or keeping a transponder for the distribution of information is primarily a business decision, not one tied to categorization of content.

In February 2008, the Ministers of Information of the Arab League met to develop a regional Satellite Broadcasting Charter (the "Charter") that would impact, even if not decisively, what signals would be carried over satellites controlled by members of the League. ${ }^{73}$ They met at a time of great regional frustration occasioned by the extraordinary abundance of satellite signals that were reshaping flows of information in the region. ${ }^{74}$ In societies where information, especially via radio and television signals, had been a highly controlled commodity - where an almost universal characteristic of governance was control over the channels of communication - the satellite revolution was providing an irksome new reality. 75 Porousness could lead to new political formations, could undermine stability, and certainly could disturb the state's long-standing control of narrative. Some countries, such as Iraq, barred antennae. With the arrival of Al Jazeera in 1996, there was a sea change, as the channel aggressively covered politics in many Middle Eastern capitals. It was an object of frustration to established autocracies because it seemed to touch an important nerve in the regional audience, which was desirous of receiving more thorough news about their leaders. ${ }^{7}$ In addition, there was the persistent concern about western channels bringing western values (or lack of values) and interfering with traditional teachings and ways of life. The state control that had been central to the nature of the state now threatened to dissipate. ${ }^{77}$

73 An English translation of the Arab Satellite Broadcasting Charter is available at "Arab Satellite Broadcasting Charter: Principles for Regulating Satellite Broadcasting Transmission in the Arab World," Arab Media E Soc'y, Feb. 2008, available at http://www.arabmediasociety.com/articles/downloads/ 20080314081327_AMS_Charter_English.pdf.

74 See "Arab TV Broadcasters Face Curbs," BBC News, Feb. 12, 2008, available at http://news.bbc.co. $\mathrm{uk} / 2 / \mathrm{hi} /$ middle_east $/ 7241723 . \mathrm{stm}$.

75 See William A. Rugh, Arab Mass Media: Newspapers, Radio, and Television in Arab Politics (Praeger 2004); see also Sakr, supra note 25.

$7^{6}$ See Marc Lynch, Voices of the New Arab Public: Iraq, Al-Jazeera, and Middle East Politics Today (Columbia University Press, 2006); The Al Jazeera Phenomenon: Critical Perspectives on New Arab Media (Mohamed Zayani ed., Paradigm Publishers 2005); Mohammed el-Nawawy and Adel Iskander, Al-Jazeera: How the Free Arab News Network Scooped the World and Changed the Middle East (Westview Press 2002); Hugh Miles, "Al Jazeera," 155 Foreign Pol'y 20 (July-Aug. 2006); Naomi Sakr, "Media Development and Democratisation in the Arab Middle East," 6 Global Dialogue 98 (Winter/Spring 2004).

77 See Rugh, supra note 75. See also Brookings Doha Center, "Forward or Backward: The 2008 Arab Satellite TV Charter and the Future of Arab Media, Society, and Democracy," at 17 (Mar. 17, 
Adopting the Charter was an attempt to control competition among satellite providers and to impose a set of restraints on what the satellite signals would provide. It was drafted to establish regional standards that would be enforced by the signatories, a mode of determining which law applied, and an internal system for complaint by one country to another with a method for ensuring some compliance with regional goals. The Charter provides guidelines as to what should be prohibited or what regulations should govern the behavior of satellite providers. These satellite providers (broadly conceived) should not, according to the Charter, "jeopardize social peace, national unity, public order and general propriety." ${ }^{8} 8$ In addition, the satellite entities should adopt standards requiring them to abstain from inciting hatred or ethnic, color, racial, or religious discrimination, from broadcasting any material that would incite violence or terrorism (interestingly, differentiating between terrorism and "resisting occupation"). Furthermore, the Charter encourages programming that reinforces the religious and ethical values of the Arab society, and prohibits satellites from broadcasting anything that would insult God, revealed religions, prophets, mazhabs (religious schools), and religious symbols of each group (with the groups included not fully identified).

There are grace notes that have the flavor of modernization. The satellite broadcasters, according to the Charter, should provide "the largest number possible of programmes and services to maintain the Arab identity and the Islamic culture and values and to highlight the Arab contribution to human civilization." They should promote dialogue and understanding among different cultures. And there is a note of political regional integration to the Charter in the call for satellite agencies to "maintain Arab identity against the negative impact of globalization and reaffirm the specificity of the Arab world." To do this, however, there should be a policy of avoiding the broadcast of "anything that would contradict or jeopardize Arab solidarity." And, of course, the channels should not insult leaders or national and religious symbols.

$\mathrm{Al}$ Jazeera, whose frequent criticisms of many Arab governments made it one of the supposed targets of the Charter, organized a panel discussion the day the Charter was issued. In a video report, one commentator pointed out that regulation of Arab satellite channels was motivated by threats to the more mature, state-based channels from "a large number of profit-seeking channels that aim to attract viewers by nudity, charlatanry, and sectarianism." 79 Competition yielded a race to the bottom, he argued, where civility would be sacrificed and sensationalism and lack of objectivity would prevail.

2008), available at http://www.brookings.edu/ /media/Files/events/2008/o317_arab_media/o317_arab_ media.pdf (comments by Saad Eddin Ibrahim).

78 "Arab Satellite Broadcasting Charter: Principles for Regulating Satellite Broadcasting Transmission in the Arab World," supra note 73.

79 "Al-Jazeera Pundits Discuss Proposed Arab Satellite TV Regulations," BBC Monitoring World Media, Feb. 20, 2008. 
A second panelist, Abd-al-Bari Atwan, editor-in-chief of Al-Quds Al-Arabi, and independent Pan-Arab newspaper based in London, represented a different current of thinking. He argued that the Charter was drafted because "the repressive, dictatorial Arab governments have begun to realize that Arab public opinion is moving strongly," and so Arab information ministers have hastened to "bury this awakening in Arab public opinion" by enacting legislation to "gag and criminalize Arab media." The priority of the ministers of information, he suggested, was to protect the regimes that made those decisions. The objective of the Charter, he argued, was not necessarily to uphold Arab values and ethics, but "to preserve those repressive measures by governments that engage in torture and corruption, squander public funds, and violate human rights." ${ }^{80}$

The Charter gives additional political cover to governments that wish to impose more restrictions, and it seems to augur a new order of pervasive licensing and authorization - or at least to legitimate more extensive supervision. ${ }^{81}$ The Charter's existence remains controversial. Some claim that the Charter is so cumbersome as to be ineffective. ${ }^{82}$ Others argue that presents no threat because the standards are a "code of honor," a form of self-regulation rather than state enforcement. ${ }^{8}{ }^{3}$ Yet already there are accounts that the Charter has served to justify additional restrictions by Egypt in contracts for the use of Nilesat; ${ }^{84}$ such restrictions might also be imposed on the use of production facilities in media cities in Egypt and elsewhere. Nevertheless, the Charter should be seen in a global context of regulation, alongside a fear of the incompatibility of satellite with domestic control of broadcast signals.

The existence of a pattern of regulation should not be used to justify suppression of dissent or other systematic modes of controlling speech. But comparative insights help in understanding what steps are being taken and in fashioning criteria for judging their appropriateness. ${ }^{85}$

80 Id

81 "Some satellite television channels based in Egypt are concerned, amid assertions by the government on the need to enforce a document regulating the work of satellite television channels. The Arab information ministers endorsed this document at an emergency meeting in Cairo last month." "Five Private Egyptian Satellite TV Channels Face Prospect of Closure, Ban,” BBC Worldwide Monitoring, Mar. 7, 2008 (quoting Khalid al-Shami’s March 6, 2008 report in Al-Quds al-Arabi).

82 "Al-Jazeera Pundits," supra note 79.

83 Id.

84 See, e.g., "Egypt's Nilesat Halts Transmission of London-Based Al-Hiwar TV," BBC Monitoring World Media, Apr. 3, 2008.

85 See "Communication from the Euromed and the Media Taskforce to the Euromed Culture Ministers" Athens (May 29-30, 2008), available at http://ec.europa.eu/external_relations/euromed/media/ athens_final_communique_0507_en.pdf. For a while, it appeared there might be a "copycat" charter for the so-called Euromed states. Having seen the criticism of the Arab Charter, the Euromed group drafted a Declaration, not a "Charter," seeking to avoid suspicion that they were moving to a binding international legal instrument. Secondly, it would be neutral from a technological point of view, dealing with any kind of audiovisual content (not only that distributed by satellite). Its scope would be any signal received in the Mediterranean area and broadcasted under the jurisdiction of any Mediterranean authority. Personal Communication from Joan Barata Mir, Catalan Regulatory 


\section{CONCLUSIONS}

This chapter describes a system in which formal law - even formal agreements among countries - may not be descriptive of governmental actions concerning hate-speechrelated content on satellites. This chapter discusses the use of explicit transparent modes for regulation and cooperation, such as the coordination effort at the EU level. Further, this chapter describes how informal relationships among states or between states and programming entities are the more relevant determinant of behavior. What emerges is the need to identify or abstract from the preceding examples which points require additional understanding. For example, we see in some aspects of the MED-TV example that control over uplinking is a site for negotiation. We can see in the case of Eutelsat and $\mathrm{Al}$ Manar that the act of making available a transponder is a second opportunity for intervention. A more formal act, certainly, is placing a satellite service on a Terrorist Exclusion List and thus criminalizing not only the broadcasting entity but also those who deal with it. We can analyze the passage of a signal from the point of production to the point of reception to determine opportunities that have been used to urge or obtain restriction.

In all of this, the role of "law" - law as a set of properly established criteria to limit governmental intervention - is fugitive and hard to capture. A state's efforts to pressure carriers of satellite signals often will be disguised and hardly subject to any jurisdiction. The state's actions may be speech-repressive and anticompetitive, but still difficult to discern. In many cases, the state will be seeking to secure greater control of the words and images that circulate within its borders. At other times, it will be seeking to prevent the diffusion of disfavored views quite broadly. There are scarce mechanisms or standards to determine what the limits to this kind of conduct should be.

There is no system of global governance with respect to satellite signals, and it is doubtful that such a system will emerge. ${ }^{86}$ The EU seeks a more transparent system

Commission ("It seeks to identify and to proclaim some common basic principles that we share both European and North-African and Middle East countries. It has been, at least, an interesting exercise of negotiation and a very hard effort in order to find a final version which could satisfy many different kind of authorities belonging to diverse legal and constitutional systems.").

86 At an early stage - in the mid-199os - the United States precluded signals from non-U.S. licensed satellites to send them to the United States, except under prescribed circumstances.

Leveraging three years of goodwill and momentum amassed by the WTO negotiations, recent U.S. policy has focused on restructuring the ISOs. In May 1996, the FCC issued a notice of proposed rulemaking known as the Domestic International Satellite Consolidation Order ("DISCO I"), which established criteria to permit foreign-based operators to offer service in the United States.

DISCO I proposed a test in which the granting of a license to a foreign operator to provide services in the United States would be contingent upon a showing that U.S.-based satellites have effective competition opportunities ("ECO-SAT test") in: (i) the home market where the foreign operator is licensed; and (ii) all "route markets" that the foreign satellite intends to service from earth stations in the United States. In light of the recent WTO agreement, however, DISCO I was reconsidered because the WTO agreement allows nondiscriminatory access to markets without consideration of where a foreign operator is licensed. 
with respect to certain kinds of content within its borders; conversely, the Arab Charter suggests a somewhat more brutal version of the exercise. In the absence of regulation, informal efforts to persuade, pressure, and even threaten satellite providers are likely to continue. We are beginning to sense patterns emerging, but it is only as the technology itself is becoming slightly overshadowed. Terrorism is the trope that has succeeded in breaking the rules of flows of information where cultural exception, fear of pornography, sweeping concerns about cultural imperialism, and fears for national identity had failed. Terrorism has brought the deacons of free expression to the table of regulation, even of clumsy intervention. What remains to be seen is whether, in this increasingly important area of speech and its distribution, there is a major shift from informal decision making, either as part of leasing or decisions in the shadow of law, toward a model of more transparent jurisdiction, with more traditional regulatory decisions and the invocation of the rule of law.

Henry Wong, Comment, "2001: A Space Legislation Odyssey - A Proposed Model for Reforming the Intergovernmental Satellite Organizations," 48 Am. U.L. Rev. 547, 565-6 (1998). 
